\title{
Reindustrialization as a strategic priority of the competitiveness of macro regions in a globalized business environment
}

\author{
Elena Prokofievna Karlina \\ Astrakhan State Technical University \\ Institute of Economics \\ Astrakhan, Russia \\ e_karlina@list.ru
}

\author{
Anna Alexandrovna Solonenko \\ Dmitrov Fishery Technology Institute \\ Moscow region, Dmitrov district, \\ Rybnoe settlement, Russia \\ ansolonenko@yandex.ru
}

\author{
Elvira Revovna Arslanova \\ Astrakhan State Technical University \\ Institute of Economics \\ Astrakhan, Russia \\ e.arslanova@mail.ru
}

\begin{abstract}
In a globalized business environment the development of national economic systems is characterized by a decrease in the rates of economic growth, due to the reduction in the share of industrial production in GDP, the number of employed and workplaces in industrial production, which is negatively reflected in the level of competitiveness of macro regions in the world markets. In this regard, the reindustrialization, as the process of restoring the place and role of industry in the economy, is recognized as a strategic priority for increasing the competitiveness of the macro regions. In Russia, the reindustrialization is an objective condition for restructuring and upgrading of industrial production on the basis of activating the processes of updating of the technological base and introducing innovations, which predetermines the development of a reindustrialization program within the strategic management of industrial development. The proposed mechanism of the program formation allows you to create a base for the development of industrial development strategies at the national and regional levels and the formation of new competitive advantages of industrial production of Russia in the world markets.
\end{abstract}

Keywords - reindustrialization, competitiveness, industrial production, strategic planning, reindustrialization program

\section{INTRODUCTION}

In a globalized business environment the development of market relations is characterized by a significant tightening of competition between macro regions, whose leadership in world markets is conditioned not only by the level of socioeconomic development, but also by the place and role of industrial production in national economic systems.

The reindustrialization as a process of restoring the place and role of industry in national economic systems at the present stage is the most significant factor in shaping the competitive advantages of particular countries and regions in a globalized business environment. In this regard, the definition of place and role, the prerequisites for the implementation of reindustrialization in the priority system of competitiveness becomes a strategically important condition for achieving world economic leadership.

The concept of reindustrialization was developed in the works of P. Marsh, J. Rifkin, K. Anderson [1,2,3] within the framework of the theory of industrial revolution, in modern Russia - in the works of S. Yu. Glazyeva, S.D. Bodrunova, O.S. Sukhareva, O.N. Voronkova $[4,5,6,7,8,9]$ and other economists. Along with this, the study and analysis of scientific research published on this subject allowed to draw a conclusion that the issues of the formation of theoretical and practical approaches to strategic planning of reindustrialization processes require concretization for a particular national economic system, taking into account the achieved level of socio-economic and technological development that determines the research objective justification of the place and the role of re-industrialization processes in the system of strategic priorities for increasing the competitiveness of industrial production in Russia.

\section{MATERIALS AND METHODS (MODEL)}

The reindustrialization as a strategic priority for increasing the competitiveness of the national economic systems was caused by the transformation of the world economy structure, the globalization of business, the recognition of the crisis of the postindustrial model and the virtual economy and the transition to a new model of economic growth oriented to the real sector of the economy: the development of industrial production on the basis of the achievements of the scientific and technological progress and a new advanced technological structure. This paradigm was called the reindustrialization or a new industrialization. 
Industry in all developed countries of the world is the determining factor of economic growth and technological progress. The decline in the share of industry in the GDP of developed countries indicates, on the one hand, high manufacturability of the industrial production, which is expressed in the reduction of the number of employees in manufacturing, the growth of its automation level, the application of robotics, the intensity of the innovation process, etc., on the other hand, it is the result of the placement of industrial production in the countries with cheaper resources.

The Research of the level and growth rates of national economic systems for the period from 2006 till 2016 allowed the authors to identify the downward trend in the growth rates of GDP (Table 1), due to the dynamics of growth rates of industrial production and the share of industrial production in GDP.
The systematization of countries in terms of growth and decline in the share of industry in GDP, as well as the dynamics of macroeconomic indicators (Table 1) allow us to state that the processes of re-industrialization have received widespread development in the USA since 2006.

It is evidenced by the growth rates of particular industrial sectors of the USA in 2010-2011 such as the production of semiconductors $-22.5 \%$, agricultural, construction and mining machinery and equipment $-15.3 \%$, cast iron and steel $-19.1 \%$, car spare parts $-17.7 \%$; industrial equipment $-19.0 \%$, engines, turbines and equipment for transfer devices -14.6\%; metal processing and coating of metals $-13.2 \%$.

At the same time, the sectors related to the fifth technological structure demonstrate a slight increase or decrease: in medical equipment and related products $+2.0 \%$, in pharmaceuticals $-2.1 \%$, in communication equipment + $2.1 \%$, in audio and video equipment $+0.1 \%$ in $2010-2011$ [11].

Table 1 - Macroeconomic indicators of countries in 2006-2016. [10]

\begin{tabular}{|c|c|c|c|c|c|c|c|c|c|c|c|}
\hline \multirow[t]{2}{*}{ Country } & \multicolumn{4}{|c|}{ GDP growth rate, $\%$} & \multicolumn{3}{|c|}{$\begin{array}{l}\text { Share of the industrial sector, } \% \\
\text { in GDP }\end{array}$} & \multicolumn{4}{|c|}{$\begin{array}{l}\text { The growth rate of industrial } \\
\text { production, } \%\end{array}$} \\
\hline & 2006 & 2014 & 2015 & 2016 & $2005-2006$ & 2013 & 2015 & 2006 & 2014 & 2015 & 2016 \\
\hline Germany & 2.8 & 1.6 & 1.7 & 1.9 & 30.0 & 30.1 & 30.4 & 4.4 & 1.9 & 0.4 & 1.3 \\
\hline Ireland & 5.7 & 5.2 & 4.8 & 5.1 & 27.0 & 28.0 & 24.9 & 5.0 & 4.0 & 3.0 & 1.2 \\
\hline France & 2.2 & 0.2 & 0.6 & 1.2 & 20.7 & 18.7 & 19.5 & 0.2 & -2.0 & 2.0 & 0.4 \\
\hline Norway & 4.6 & 2.2 & 0.9 & 1.1 & 43.5 & 42.3 & 35.0 & 1.8 & 0.8 & 0 & -0.5 \\
\hline USA & 2.9 & 2.2 & 2.9 & 1.5 & 20.9 & 19.5 & 19.4 & 4.2 & 2.9 & -0.7 & -1.2 \\
\hline Canada & 2.9 & 2.5 & 0.9 & 1.5 & 29.1 & 28.4 & 28.2 & 2.9 & 3.9 & -0.7 & 0.5 \\
\hline India & 9.4 & 7.2 & 8.0 & 7.1 & 27.9 & 25.8 & 29.7 & 7.5 & 1.8 & 2.5 & 5.2 \\
\hline China & 11.1 & 7.7 & 6.9 & 6.7 & 24.0 & 43.9 & 40.9 & 22.9 & 7.3 & 6.9 & 6.1 \\
\hline Russia & 6.7 & 0.7 & -2.8 & -0.2 & 39.3 & 37.5 & 32.5 & 4.8 & 1.7 & -0.8 & 1.3 \\
\hline Belarus & 9.9 & 1.6 & -3.6 & -2.6 & 41.7 & 46.2 & 41.3 & 15.6 & 3.5 & -5.7 & -0.4 \\
\hline Kazakhstan & 10.6 & 4.3 & 1.5 & 1.1 & 39.8 & 37.9 & 32.5 & 7.7 & 0.3 & 0.8 & 1.4 \\
\hline
\end{tabular}

The reindustrialization policy pursued by the US Government, the main directions of which are: the change in the taxation of industrial enterprises, the increase of state assistance to industrial development, reshoring - "return home" of manufacturing enterprises, was the reasons for this situation.

The significance of reindustrialization for European countries increased after the crisis of 2008, which revealed all the shortcomings of post-industrial society's development: the intensification of migration processes, which contributes to the growth of unemployment, the job cuts in the industry, and the slowing pace of industrial production growth. For example, from 2000 to 2012 the number of workplaces in industry decreased in the UK by $35 \%$, Portugal by $33 \%$, Ireland by $29.4 \%$, Spain by $22.8 \%$, France by $22 \%$. In Italy, during the same period, output of industrial products decreased by $11.1 \%$, Greece - by $10 \%$, Britain - by $9.2 \%$, Spain - by $7.4 \%$. The average unemployment rate in the countries of the European zone is $11.8 \%$ [11].

It should be particularly noted the place and role of Germany in the economic development of the countries of the European Union. The optimal structure of the economy (the share of the industrial sector in GDP is $30.4 \%$ in 2015), specialization in the production of high- and mediumtechnology products (machinery, electrical engineering, automotive industry, chemical industry, including pharmaceuticals, account for $54 \%$ of industrial output), moderate growth in wages, the implementation of a set of government measures to preserve jobs in the automotive and mechanical engineering industries, a stable surplus of foreign trade activity, rational geographic product diversification of imports and exports have allowed Germany to minimize the consequences of the crisis of 2008 and to maintain its leading position in the economy of the European Union.

However, changes in the structure of the world economy had an impact on the industrial development of Germany: the growth of labor productivity and automation led to job cuts in the industry by $4.4 \%$ from 2000 to 2013 [12].

Thus, the current situation in European countries in the post-crisis period has forced to reconsider the imperatives of economic policy, highlighting the reindustrialization as the main thing.

In Russia the need for reindustrialization as a set of organizational, economic, legal, technological measures aimed at increasing the competitiveness of industrial production is caused by the following reasons [10]: 
- decrease in the share of industrial production, including manufacturing industry (from $17.7 \%$ in 2010 to $13.6 \%$ in 2015) in GDP; the fall in the growth rate of the production of manufacturing industry from $10.6 \%$ in 2010 to $0.1 \%$ in 2016 , including high-technology processing types of economic activity from $13.1 \%$ in 2012 to $3.0 \%$ in 2016); a high degree of depreciation of fixed assets (46.9\%), an increase in the share of the completely worn out active part of the fixed assets of the manufacturing industry $(22.0 \%$ in 2016) allow us to conclude that the Russian industry as a whole and manufacturing industries in particular are deindustrialized;

- reduction in the share of costs for technological innovation in the total volume of shipped goods, performed work, services of processing enterprises $(2.2 \%$ in 2013 and $1.8 \%$ in 2015) and internal costs on Research and Development in GDP of the RF $(1.13 \%$ in 2010 and $1.1 \%$ in 2016); low level of development of advanced production technologies - less than $1 \%$ in the total number used for all types of activities $(0.86 \%$ in 2015$)$; the introduction of antiRussian sanctions (the number of new technologies (technical achievements) acquired by organizations, software tools in manufacturing industries decreased by $53.9 \%$ : from 11832 units in 2010 to 7687 units in 2016) predetermined a slowdown in the process of renewal of production technologies;

- the import substitution processes implemented in 2014-2016 are a response to the current situation in the economy: according to the Russian Federal State Statistics Service (Rosstat) the share of imports of food products and agricultural raw materials (except textile) for their production decreased from $14.5 \%$ in 2015 to $11.2 \%$ in September of 2016, though the indicator for the group "machinery and equipment" has increased - from $44.8 \%$ to $51.2 \%$, which indicates the need of activity revitalization to create new hightech enterprises for the production of machinery and equipment, and, in turn, will restore the whole chain of generating the added value in other sectors.

\section{RESULTS AND DISCUSSION}

For Russia the solution of these problems is possible within the reindustrialization program as an "economic policy representing a set of measures ... aimed at the planned restoration (creation, modification) of the industrial and technological basis of the economic system through macroeconomic, institutional, organizational, legal, structural and investment measures"[7].

The need for reindustrialization (neoindustrialization) in Russia is substantiated in the works of S.Yu. Glazyeva, S.D. Bodrunova, O.S. Sukhareva, O.N. Voronkova and other economists, who admit de-industrialization as the most significant reason for its implementation.

In Russia, the process of deindustrialization of industry was due to structural and institutional transformations of the 1990s, which resulted in a reduction in the share of industrial production in GDP, the number of employed, the prevalence of the use of the achievements of the fourth technological structure, the high specific gravity of the import component and, consequently, low manufacturability of industrial products [13].
However, currently the place and role of reindustrialization as a strategic priority for increasing the competitiveness of industrial production has not been adequately reflected in program and regulatory documents. Thus, in Federal Law of June 28, 2014 No.172-FL "About State Strategic Planning in the Russian Federation" and Federal Law of December 31, 2014 No. 488-FL "About Industrial Policy in the Russian Federation" the concept of "reindustrialization" is absent, that allows to affirm about the expediency of its program development within the strategic management system (Figure 1).

The formalization of the procedure for the formation of the program of reindustrialization in the system of strategic management implies a consistent set of processes (planning, organization, control) characterized by a set of interrelations and interactions aimed at resolving modernization issues of priority industries based on the creation of high-tech industries.

The main requirements for this mechanism are:

- the mechanism for the formation of the reindustrialization program should be focused on the final result of the industrial development strategy of the Russian Federation and should develop such a system of incentives that would ensure " equal profitability" achievement of all the objectives of industrial systems. In addition, the mechanism should include the possibility of state regulation of priorities of certain goals, providing the current state of industry and the level of economic development of the country;

- the mechanism should take into account the boundaries of the legal and economic enterprise autonomy and their associations in determining (within their competence) the objectives, selecting and implementing means of achieving them, and include the system of regulators of legal, economic and industrial relations among individual enterprises, enterprises and government authorities;

- the mechanism should be adapted to the objectively existing discrepancy and contradictory interests of stakeholders in the sphere of industry, certain groups of workers and executive bodies in the sphere of industry. Accordingly it must develop the order of application of this or that stimulus taking into account its influence on the behavior of specific groups of people or enterprises.

Thus, reindustrialization in Russia as a key task to increase the competitiveness of industrial production should be carried out within the framework of a single industrial policy that integrates all industry-oriented state sector programs as well as regional programs related to restoring the competitive industrial potential of regions and macro regions. 


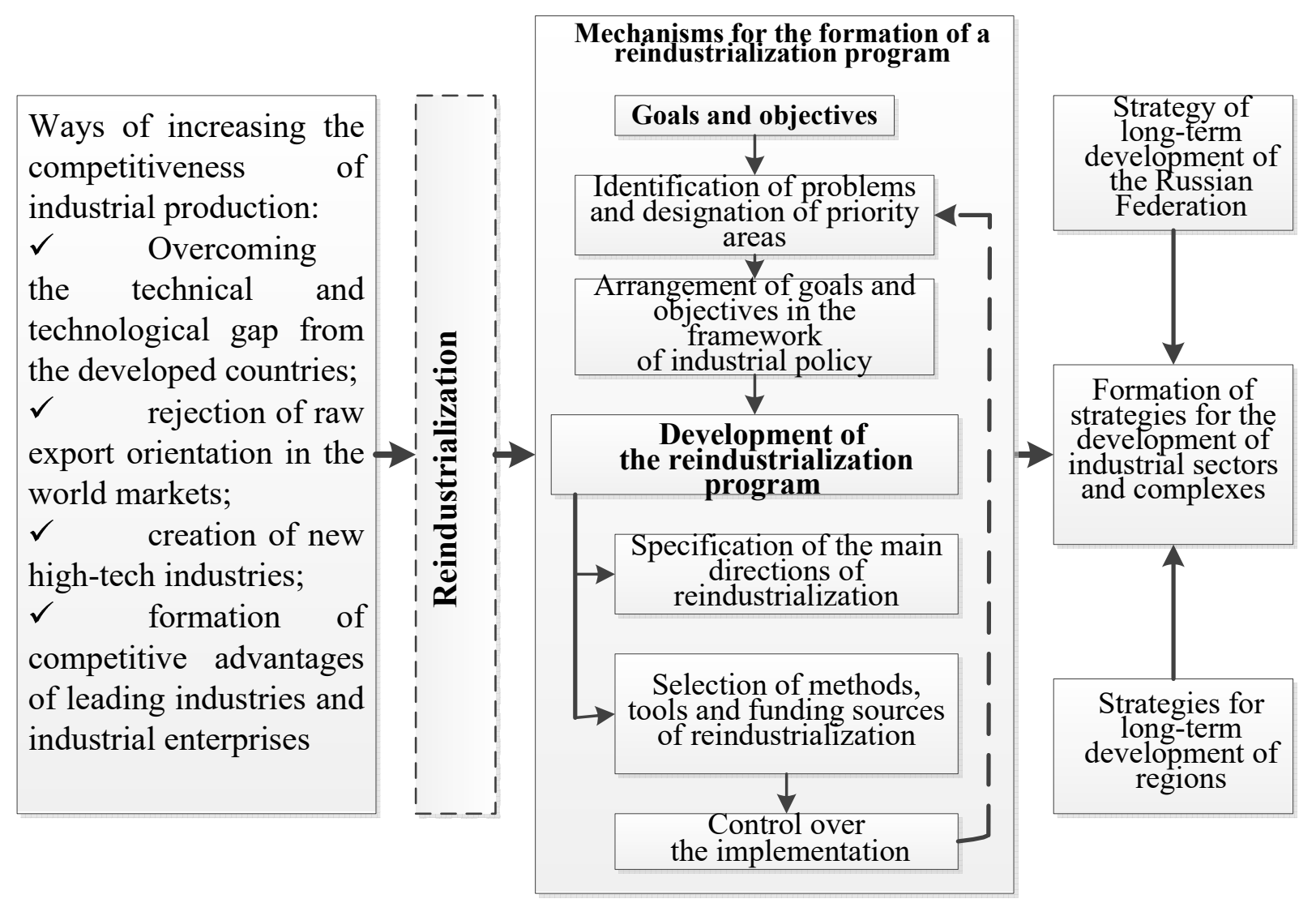

Figure 1. The place and role of reindustrialization in the system of strategic management of Russia

\section{CONCLUSION}

A. As a result of the comparative characteristics of the goals of re-industrialization and the mechanisms for their achievement in national economic systems, the following conclusions have been formulated:

- the process of reindustrialization in the world economy was predetermined by the need to restore the place and role of industry in the structure of GDP of national economies as the main competitive advantage in a globalized business environment;

- the main directions of reindustrialization in the USA and Europe are: implementation of the energy strategy for improving the accessibility and reducing the cost of energy and reshoring manufacturing enterprises;

- the restructuring and modernization of industry on the basis of strengthening the place and role of state participation are the main directions of reindustrialization in Russia.

$B$. Taking into account the place and the role of reindustrialization as a strategic priority of increasing the competitiveness of industrial production, it is proposed to include a reindustrialization program in the strategic planning system of Russia's industrial development, which allows creating a basis for forming long-term development strategies at national and regional levels and enhancing the competitive potential of industrial production.

\section{References}

[1] P. Marsh, "New Industrial Revolution. Consumers, globalization and the end of mass production," trans. from English. A. Sholomitskaya, Moscow, Publishing House of Gaidar Institute, 2015. - 420 p. [Marsh P. Novaya promyshlennaya revolyutsiya. Potrebiteli, globalizatsiya i konets massovogo proizvodstva / per. s angl. A. Sholomitskoy. - M.: Izd-vo Instituta Gaydara. 2015. - 420 s.] [2] J. Rifkin, "The Third Industrial Revolution. As horizontal interactions change the energy, the economy and the world as a whole," Moscow, Alpina non-fiction, 2014. - 410 p. [Rifkin Dzh. Tret'ya promyshlennaya revolyutsiya. Kak gorizontal'nyye vzaimodeystviya menyayut energetiku, ekonomiku i mir v tselom. - M.: Al'pina non-fikshn. 2014. $410 \mathrm{~s}$.

[3] C. Anderson, Makers: "The New Industrial Revolution," NY: Random House. 2012. -598p.

[4] S.Yu. Glazyev Scientific report: "On the goals, problems and measures of the state policy of development and integration," Moscow, January 29, 2013 http://www.elitat.ru/?rub=3\&st=4601\&type $=3$ [S.YU. Glaz'yev Nauchnyy doklad: «O tselyakh, problemakh i merakh gosudarstvennoy politiki razvitiya i integratsii». Moskva. 29 yanvarya $2013 \mathrm{~g}$.] 
[5] S.D. Bodrunov, "Reindustrialization of the economy as a strategic priority of Russia's development," Economy of quality, 2014, 4(8),electronic journal www.eq-journal.ru [Bodrunov S.D. Reindustrializatsiya ekonomiki kak strategicheskiy prioritet razvitiya Rossii// Ekonomika kachestva. 2014. №4(8). elektronnyy zhurnal]

[6] S.D. Bodrunov, "Reindustrialization of the Russian economy: opportunities and restrictions," Abalkin Readings, Round table "Economic growth of Russia", December 11, 2013.Access mode:http://inir.ru/wpcontent/uploads/2014/04/Reindustrialization of the Russian economy-opportunities-and-restrictions.Pdf 6 [Bodrunov S.D. Reindustrializatsiya rossiyskoy ekonomiki: vozmozhnosti i ogranicheniya. //Abalkinskiye chteniya. Kruglyy stol «Ekonomicheskiy rost Rossii». 11 dekabrya 2013.- Rezhim dostupa: http://inir.ru/wpcontent/uploads/2014/04/Reindustrializatsiya-rossiyskoyekonomiki-vozmozhnosti-i-ogranicheniya.pdf 6]

[7] O.V. Sukharev, "Reindustrialization of the Russian economy and technological development," Priorities of Russia, 10 (247), pp.2-16. [Sukharev O.V. Reindustrializatsiya ekonomiki Rossii i tekhnologicheskoye razvitiye// Prioritety Rossii.2014. 10 (247) .S.2-16.].

[8] O.S.Sukharev, "Problems of the implementation of Russia's structural policy,” Federalism, 2013,. № 4, pp. 49-60. [Sukharev O. S. Problemy realizatsii strukturnoy politiki Rossii // Federalizm. 2013. № 4. S. 49 -60].

[9] O.N. Voronkova, "Reindustrialization and neoindustrialization as the concept of adaptive development of countries in the modern world economy," in SWorld Journal, Vol.J11517 (Scientific world, Ivanovo, 2015) - URL: http://www.sworldjournal.com/e-journal/j11517.pdf (date: March 13, 2015) - pp.27-33 - Article CID Number J11517004

[10]Federal State Statistics Service (Rosstat) http://www.gks.ru/wps/wcm/connect/rosstat_main/rosstat/ru/st atistics/economydevelopment/

[11] S.A. Pobyvaev, S.A. Tolkachev, "Reindustrialization in the USA and the EU," http://elib.fa.ru/art2015/bv2750.pdf/download/bv2750.pdf

[Pobyvayev S.A.. Tolkachev S.A. Reindustrializatsiya v SSHA i YES].

[12] B.E. Zaritsky, "Europe: reindustrialization versus deindustrialization,” Economic sciences, №8(117), pp.169175. [Zaritskiy B.Ye. Yevropa: reindustrializatsiya v sravnenii s deindustrializatsiya//Ekonomicheskiye nauki.2014. №8(117). S.169-175.].

[13] E.P. Karlina, A.S. Fartushina, M.A. Grigoriev, "Publicprivate partnership as an instrument for the reindustrialization of the shipbuilding cluster," Vestnik of Astrakhan state technical University. Series: Economics. 2016, № 4, pp. 4-10. [Karlina E.P., Fartushina A.S., Grigor'yev M.A. Gosudarstvenno-chastnoye partnerstvo kak instrument reindustrializatsii sudostroitel'nogo klastera. Vestnik Astrakhanskogo gosudarstvennogo tekhnicheskogo universiteta. -Seriya: Ekonomika.- 2016.- № 4.- S. 4-10.]. 